
Т. М. МУРАТОВА 1 , Д. М. ХРАМЦОВ С. С. ЛАРЧЕНКО, С. О. МАЛОНОГА

\title{
ДОГОСПІТАЛЬНА МЕДИЧНА ДОПОМОГА ПРИ ГОСТРИХ ПОРУШЕННЯХ МОЗКОВОГО КРОВООБІГУ. ПЕРШ РЕЗУЛЬТАТИ РЕФОРМИ НА ПРИКЛАДІ ОДЕСЬКОЇ ОБЛАСТІ
}

\author{
${ }^{1}$ Одеський національний медичний університет, м. Одеса, Україна \\ ²Південний міжрегіональний департамент Національної служби охорони здоров'я України, \\ м. Одеса, Україна \\ зКНП «Одеський обласний центр екстреної медичної допомоги і медицини катастрофр», \\ м. Одеса, Україна
}

\begin{abstract}
Мета: оцінити ефективність надання догоспітальної допомоги при інсульті в контексті реформування національної системи охорони здоров'я на прикладі Одеської області.

Матеріали і методи. Здійснено ретроспективний аналіз діяльності екстреної медичної допомоги (ЕМД) у 20162018 рр. (до впровадження ресорми) та в 2018-2019 рр.

Результати. Проведений аналіз показав, що в середньому щороку в області через систему екстреної медичної

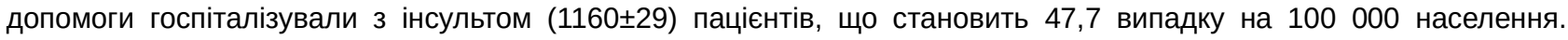
Середній вік госпіталізованих пацієнтів становив $(62,6 \pm 3,8)$ року, при гендерному співвідношенні 1/1,2 із незначним переважанням чоловіків. Найбільшу кількість випадків гострих порушень мозкового кровообігу (ГПМК) засріксовано влітку (61,4 \%). Близько 25-30 \% викликів екстреної медичної допомоги не завершуються госпіталізацією хворого з інсультом. Причини відмови пов'язані з бажанням хворого або його родичів лікуватися амбулаторно (13,5 \%), наявністю серед родичів лікарів або середніх медичних працівників (11,7 \%), браком коштів (18,9\%), сімейними обставинами (6,3 \%), загальним тяжким станом хворого (4,5 \%). Після введення у дію нової концепції екстреної медичної допомоги кількість відмов від госпіталізації за наявності інсульту зменшилася у 2,5 раза, кількість пацієнтів, яких доставили до лікарні в рамках терапевтичного вікна, зросла на 36,3 \%. Обговорюють досвід створення регіональних клінічних та транспортних протоколів для максимального скорочення часу і забезпечення оптимального лікування на всіх етапах медичної допомоги.

Висновки. Впровадження реформи покращило якість догоспітальної допомоги при інсульті, так кількість відмов від госпіталізації за наявності інсульту зменшилася в 2,5 раза, кількість пацієнтів, яких доставили до лікарні в рамках терапевтичного вікна, зросла на 36,3 \%. Залишається актуальною проблема необґрунтованих відмов пацієнтів із ГПМК та їхніх родичів від термінової госпіталізації. Обговорюють впровадження стандартизованих операційних процедур надання догоспітальної допомоги, спрямованих на зменшення часу транспортування пацієнтів до стаціонару.
\end{abstract}

КЛЮЧОВІ СЛОВА: гостре порушення мозкового кровообігу; догоспітальний етап; медична допомога; охорона здоров'я.

Гострі порушення мозкового кровообігу (ГПМК) залишаються однією з провідних причин захворюваності, інвалідизації та смертності у розвинутих країнах $[6,12,21]$. ГПМК не тільки впливають на індивідуальне й громадське здоров'я, але й суттєво збільшують видатки на соціальні програми підтримки хворих, які перенесли інсульт [21]. У зв'язку з цим, все більше уваги приділяють питанням оптимізації екстреної та невідкладної допомоги при ГПМК, у тому числі на догоспітальному етапі $[1-3,8,10]$.

На жаль, досі лише незначна кількість пацієнтів доставлена до спеціалізованого стаціонару впродовж терапевтичного вікна $[1,2,15,23,26$, 29]. У зв'язку з цим, запропоновані різноманітні стратегії, які дозволяють збільшити шанси на вчасне отримання реперфузійного лікування, для цього застосовують мобільні інсультні центри (mobile stroke units, MSUs) на базі наземного та авіатранспорту, розширюють мережу лікарень, які готові надати спеціалізовану допомогу при ГПМК (stroke ready hospitals), розвивають телемедичні технології [6, 9-11, 16-19, 22, 24]. В останні роки у світі проводять рандомізовані контрольовані дослідження, які присвячені оцінці ефективності застосування нейропротекторних, антигіпертензивних та тромболітичних засобів на догоспітальному етапі [20, 25, 27].

У 2017 р. прийнято Закон України «Про державні фрінансові гарантії медичного обслуговування

() Т. М. Муратова, Д. М. Храмцов, О. М. Стоянов, Ю. М. Ворохта, Д. О. Самофалов, С. С. Ларченко,

С. О. Малонога, 2020 
населення». Відповідно до Закону, в Україні всім пацієнтам гарантовано доступ до медичних послуг та лікарських засобів, пов'язаних із наданням екстреної медичної допомоги, первинної медичної допомоги, спеціалізованої та високоспеціалізованої медичної допомоги, паліативної реабілітації та медичної допомоги, а також медичної допомоги у зв'язку з вагітністю та пологами.

Лікування інсульту визначено серед пріоритетних напрямків, і тому система інсультної допомоги в Україні потребує серйозного реформування та вдосконалення [5].

Закон про екстрену медичну допомогу прийнятий у 2014 р., концепція рефрорми екстреної медичної допомоги в Україні оприлюднена у 2018 р. Основними її завданнями є вдосконалення підготовки немедичних працівників; стандартизація медичної допомоги на принципах доказової медицини; впровадження загальнопрофрільних медичних стандартів із фрормуванням бригад парамедиків; навчання персоналу відповідно до нових програм; вдосконалення роботи диспетчерської служби центрів екстреної медичної допомоги та медицини катастроф і створення відділень екстреної та невідкладної медичної допомоги [4]. Утім, незважаючи на суттєвий поступ у реорормуванні вітчизняної системи екстреної та невідкладної допомоги, кількість публікацій з питань її організації та практичної реалізації декларованих принципів $є$ невисокою.

Мета дослідження: оцінити ефективність надання догоспітальної допомоги при інсульті в контексті реформування національної системи охорони здоров'я на прикладі Одеської області.

Матеріали і методи. Дослідження проводили на базі підрозділів КНП «Одеський обласний центр екстреної медичної допомоги і медицини катастроф». Здійснювали ретроспективний аналіз діяльності екстреної медичної допомоги (ЕМД) у 2016-2018 рр. (до впровадження ресорми) та в 2018-2019 рр. Оцінювали частоту госпіталізацій пацієнтів 3 інсультом бригадами ЕМД, частоту та структуру відмов від госпіталізації, кількість пацієнтів, які доставлені до спеціалізованого стаціонару впродовж терапевтичного вікна (4,5 години) для системного тромболізу. Проаналізували вікову структуру госпіталізованих. Статистичну обробку проводили за допомогою описової статистики з використанням програмного забезпечення Statistica 10.0 (Dell StatSoft Inc., США).

Результати дослідження та їх обговорення. Проведений аналіз показав, що в середньому щороку в області через систему ЕМД госпіталі-

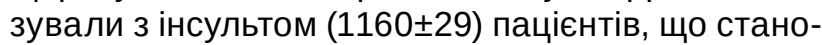
вить 47,7 випадку на 100000 населення (табл. 1).

Таблиця 1. Частота госпіталізацій бригадами екстреної медичної допомоги пацієнтів із гострими порушеннями мозкового кровообігу (2016-2019 рр.)

\begin{tabular}{|c|c|c|c|c|c|c|}
\hline \multirow{3}{*}{ Роки } & \multicolumn{3}{|c|}{ Одеська область } & \multicolumn{3}{|c|}{ м. Одеса } \\
\hline & \multirow{2}{*}{$\begin{array}{c}\text { кількість } \\
\text { госпіталізацій }\end{array}$} & \multicolumn{2}{|c|}{ кількість відмов } & \multirow{2}{*}{$\begin{array}{c}\text { кількість } \\
\text { госпіталізацій }\end{array}$} & \multicolumn{2}{|c|}{ кількість відмов } \\
\hline & & абс. & $\%$ & & абс. & $\%$ \\
\hline 2016 & 224 & 63 & 28,1 & 945 & 274 & 29,0 \\
\hline 2017 & 218 & 55 & 25,2 & 938 & 256 & 27,3 \\
\hline 2018 & 222 & 29 & 13,1 & 914 & 88 & 9,6 \\
\hline 2019 & 246 & 32 & 13,0 & 933 & 97 & 10,4 \\
\hline
\end{tabular}

Утім, відповідно до звітної документації стаціонарів, середня чисельність госпіталізацій хворих із ГПМК складає близько 7000, тобто більше 80 \% хворих поступають до стаціонарів поза системою ЕМД (самозвернення, приватні мережі швидкої/ екстреної допомоги).

Середній вік госпіталізованих за ЕМД пацієнтів становив $(62,6 \pm 3,8)$ року, при гендерному співвідношенні 1/1,2 із незначним переважанням чоловіків. Найбільшу кількість випадків ГПМК зафріксовано влітку (61,4 \%). Це можна пояснити як особливостями степового клімату, притаманного більшій частині Одеської області, так й значною кількістю осіб, які відпочивають 3 інших регіонів країни, в тому числі хворих на захворювання серця та судин із високим ризиком розвитку інсульту.

При врахуванні кількості госпіталізованих із ГПМК, за даними форми фр. 66 та звітів обласного невролога, рівень захворюваності на ГПМК складає близько 287 випадків на 100000 населення. Ця величина $€$ порівнюваною із даними щодо захворюваності на ГПМК в Україні. За даними МО3 України, щороку реєструють 100 000110000 інсультів (понад третина 3 них - у людей працездатного віку), 30-40 \% хворих на інсульт помирають упродовж перших 30 днів і до 50 \% - протягом року від початку захворювання; 20-40 \% хворих, які вижили, стають залежними від сторонньої допомоги (12,5 \% первинної інвалідності) і лише близько $10 \%$ повертаються до повноцінного життя [2]. Втім чисельність осіб, госпіталізованих із приводу ГПМК у стаціонари Одеської області бригадами ЕМД, майже у 2,5 раза менша загальнонаціонального рівня захворюваності. Причинами такої невідповідності може бути самостійне звернення хворих до 
лікувально-профілактичних закладів та/або відмова пацієнтів від госпіталізації, рекомендованої бригадою ЕМД, а також розбіжності діагнозів у звітності ЕМД та стаціонарів.

У зв'язку із цим, значний інтерес становило питання - як часто хворі та їхні родичі відмовляються від госпіталізації. На жаль, близько 25-30 \% викликів бригад екстреної медичної допомоги не завершуються госпіталізацією хворого 3 інсультом. Причини відмови пов'язані з бажанням хворого або його родичів лікуватися амбулаторно
(13,5 \%), наявністю серед родичів лікарів або середніх медичних працівників (11,7 \%), браком коштів (18,9\%), сімейними обставинами (6,3 \%). У більшості випадків (42,3 \%) в медичній документації була відсутня інорормація щодо причин відмови від госпіталізації. У поодиноких випадках відмова від госпіталізації була зумовлена загальним тяжким станом хворого (4,5\%). В одному 3 випадків як причину відмови вказано анекдотичне (хвора не бажає залишати 30 котів). Структуру відмов наведено на рисунку 1.

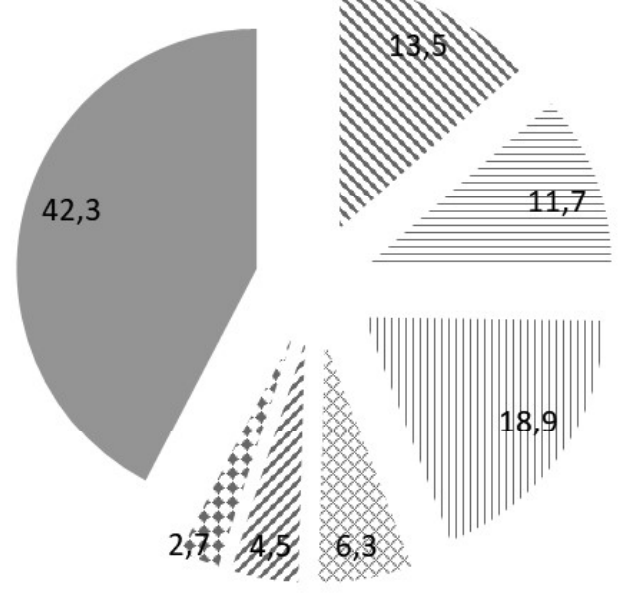

\section{бажання лікуватися амбулаторно \\ 三родич-медпрацівник}

|| брак коштів

жімейні обставини

\%. тяжкий стан хворого

:: інші

не вказано

Puc. 1. Структура відмов від госпіталізації (дані 2016-2018 рр.).

Встановлено, що після введення у дію нової концепції екстреної медичної допомоги кількість відмов від госпіталізації за наявності інсульту зменшилася у 2,5 раза, кількість пацієнтів, яких приймають до лікарні в рамках терапевтичного вікна, зросла на 36,3\%.

На сьогодні у світі при наданні догоспітальної допомоги використовують дві основні концепції. Перша, традиційна, вимагає термінового транспортування пацієнта з ГПМК до спеціалізованого інсультного центру. При цьому болюс вводять відразу після проведення КТ-скринінгу та виконання ургентних аналізів. Час «двері-голка» (DNT) при цьому складає 40-60 хв, утім з врахуванням терміну від моменту, коли пацієнта з ГПМК останнього разу бачили здоровим, та часу на транспортування хворого до лікарні $є$ ризик не вкластися у 4,5-годинне терапевтичне вікно для проведення системного тромболізису (рис. 2).

Концепція мобільного stroke unit (MSU) вперше запропонована в 2003 р. та реалізована в клінічній практиці у 2008 p. Fassbender et al. в Саарландському університеті, Німеччина [17]. Ця стратегія «наближення лікарні до пацієнта» дуже скоротила час між виникненням патології та початком лікування $[11,17]$. Це суттєво збільшило якість допомоги за рахунок покращення клінічних вислідів. Утім наприкінці 2019 р. лише
20 країн світу мали досвід застосування MSU [11]. Широкому застосуванню концепції перешкоджає висока вартість спеціалізованого автотранспорту, обладнаного експрес-лабораторією та КТ-апаратом, а також недостатній розвиток транспортної інфрраструктури. Дослідження щодо довгострокових результатів, економічної ефективності та найкращого використання MSU показують, що навіть при використанні традиційного підходу існує можливість суттєво скорити час транспортування пацієнта до спеціалізованої клініки. Це потребує інфрормування населення про необхідність якомога скорішого звернення за ЕМД при виникненні симптомів інсульту, пренотифрікації лікарні, в яку мають доставити хворого, за допомогою телефону або месенджерів соціальних мереж, скорочення часу прибуття за адресою та на транспортування хворого до найближчої спеціалізованої клініки. На жаль, не всі профільні неврологічні відділення в Україні мають у своєму складі інсультні центри, здатні виконувати системний тромболізис. Кількість ж репероруійних центрів, які здатні виконувати ендоваскулярні інтервенції, залишається невисокою. Втім за останні роки позначилася позитивна тенденція до збільшення числа реперфузійних центрів в Україні - станом на кінець 2019 р. їх було більше 50 [7]. На жаль, вони переважно сконцентровані у 


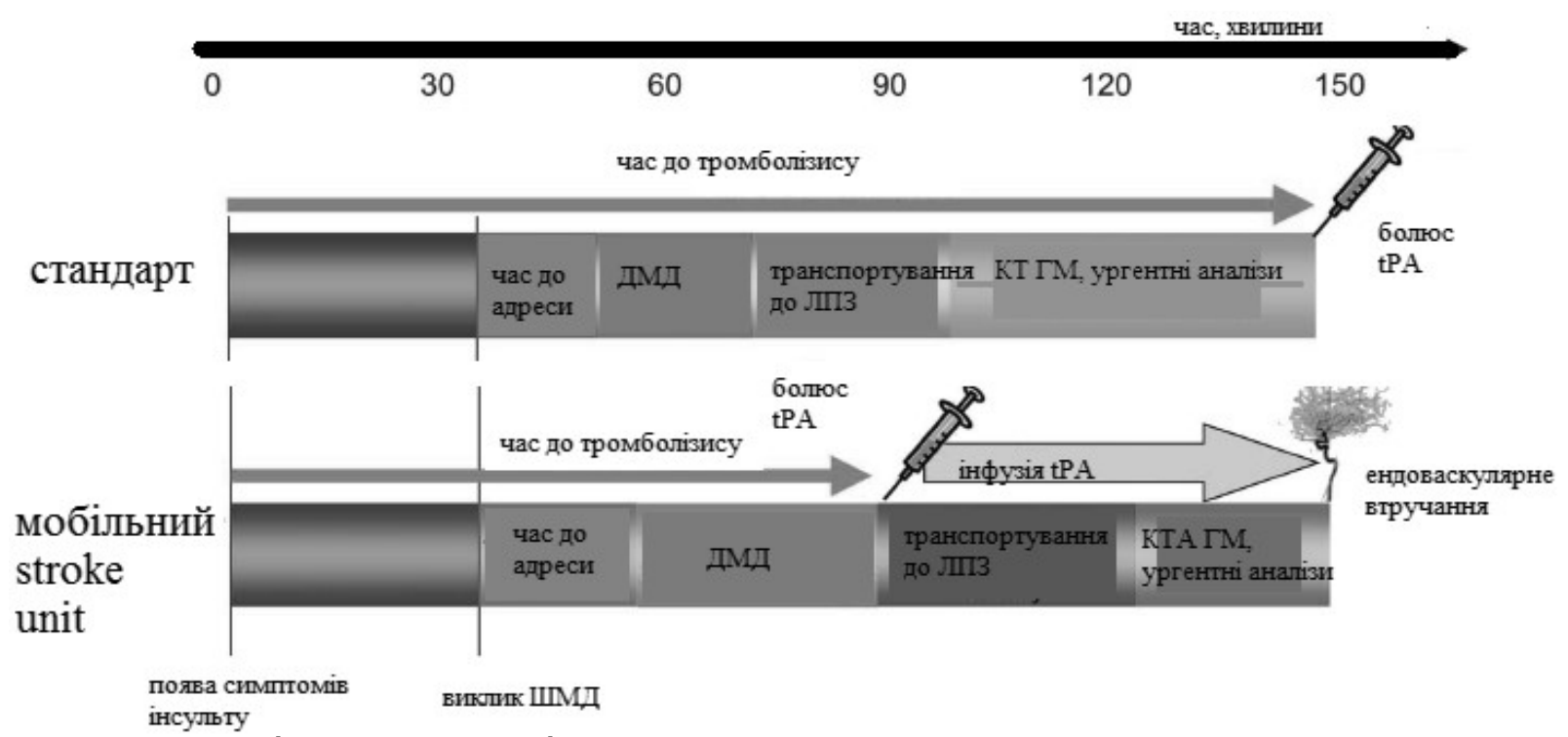

Рис. 2. Концепції надання догоспітальної медичної допомоги при гострих порушеннях мозкового кровообігу (Н. Audebert et al., 2013 із змінами).

великих містах, багато населених пунктів знаходяться поза радіусом транспортної доступності для надання високоспеціалізованої реперфузійної допомоги.

Загалом, внутрішньовенний тромболізис із рекомбінантним тканинним плазміногенним активатором (rtPA) - це стандарт допомоги при гострому ішемічному інсульті 3 доведеною ефективністю. Однак у випадку, коли інсульт викликаний оклюзією великих судин, переваги має ендоваскулярна реканалізація. Втім навіть в економічно розвинутих країнах не більше 5 \% пацієнтів мають доступ до сучасних інтервенційних технологій при тому, що оклюзія великих судин є причиною ішемічного інсульту в 10-25 \% випадків [21, 28].

У зв'язку з тим, що сучасні реперфузійні центри не завжди доступні для хворого, іноді реалізується двоетапна схема надання допомоги, коли спочатку лікарі ЕМД доставляють пацієнта до найближчої клініки, у структурі якої є інсультний блок (SU) базового рівня, а потім вже його переводять до спеціалізованого центру (comprehensive stroke center, CSC) для виконання тромбоектомії (парадигма «drip \& ship»). Порівняно з прямим направленням до CSC (парадигма «mothership»), такий підхід дає затримку в 1,5-2 год навіть в умовах високорозвинутої мережі лікувально-профрілактичних закладів [14].

щодо догоспітальної допомоги при геморагічному інсульті, то вищевказані принципи є придатними й у цьому випадку. При терміновому транспортуванні пацієнтів до спеціалізованих центрів пацієнту значно швидше можуть бути виконані нейрохірургічні втручання, зокрема встановлення шлуночкових дренажів, проведення хірургічної декомпресії, нейроінтенсивної терапії [29].

У 2019 р. в Одеській області репрезентований регіональний клінічний маршрут пацієнта (екстреної, первинної, вторинної (спеціалізованої) і третинної (високоспеціалізованої) медичної допомоги) при ішемічному інсульті. Основною метою цього регіонального клінічного маршруту пацієнта $€$ створення ефективної регіональної системи надання невідкладної допомоги пацієнтам із гострим ішемічним інсультом в Одеському регіоні та впровадження реперфузійних методів лікування (системний тромболізис із подальшою внутрішньосудинною тромбоекстрацією) в цілодобовому режимі з чіткою спадкоємністю між медичними закладами різних рівнів. Найважливішими компонентами системи є рання діагностика, організація реперфузійної терапії для максимальної кількості пацієнтів у період найбільших терапевтичних можливостей («терапевтичного вікна»), проведення алгоритму реперфузійної терапії в найкоротші терміни від початку захворювання. Обґрунтування і положення цього регіонального клінічного маршруту пацієнта основані на доказах (evidence - based medicine) і мають конкретні посилання на джерела доказової медицини (клінічне керівництво, третинні джерела), які створювались на основі даних міжнародних клінічних досліджень, мета-аналізів, систематизованих оглядів літератури тощо.

Концепція «час - мозок» означає, що допомога при інсульті повинна бути екстреною [2, 13]. Від якості та своєчасного надання цієї допомоги залежить здоров'я, а в багатьох випадках - і життя людини. Надання адекватної, ефективної та кваліфікованої допомоги можливе лише за умов своєчасної діагностики та лікування цієї патології. Крім того, для досягнення кращих результатів інсульту необхідна продуктивна співпраця служби екстреної медичної допомоги, радіологічної, неврологічної та нейрохірургічної служб, організація невідкладного поетапного діагностичного обстеження 
і лікування за загальноприйнятими стандартами. Такі стратегії, як телемедицина та повітряний медичний транспорт можуть збільшити доступність тромболітичної терапії у віддалених районах області та сільській місцевості. Необхідне створення клінічних та транспортних протоколів для максимального скорочення часу і забезпечення оптимального лікування на всіх етапах медичної допомоги.

У зв'язку з географрічними особливостями Одеси і Одеської області виділені зони транспортної доступності, у центрі кожної з яких знаходиться спеціалізований лікувально-профілактичний заклад із можливістю лікування інсульту, який може забезпечити нейровізуалізацію в режимі 24/7. Радіус охоплення населених пунктів визначається часом доїзду, який має не перевищувати 90 хв. На прибуття за адресою, згідно з цією програмою, відводиться до 20 хв, на опитування і пренотифікацію - до 10 хв. На сьогодні в Одеській області наявні 14 лПз з можливістю лікування інсульту, 7 з яких знаходиться безпосередньо у м. Одесі. Це КУ «Одеська обласна клінічна лікарня», К3 «Білгород-Дністровська міськрайонна багатопрофільна лікарня», КУ «Арцизька центральна районна лікарня», КНП «Дунайська обласна лікарня» Одеської обласної ради, КУ «Любашівська центральна районна лікарня», КУ «Подільська міська лікарня», КУ «Центральна районна лікарня Балтського району», КУ «Міська клінічна лікарня № 1», КУ «Міська клінічна лікарня № 5», КУ «Міська клінічна лікарня № 10», Центр реконструктивної та відновної медицини (Університетська клініка) ОНМедУ, медичний центр «Into - Sana», медичний центр «Клініка Святої Катерини», TOB «Дім медицини» ODREX. Пацієнти з ГПМК поза межами терапевтичного вікна - мешканці районів області, їх доставляють у відповідні центральні районні лікарні, за необхідності здійснюють подальше транспортування до найближчого центру нейровізуалізації з метою уточнення терапевтичної тактики. Враховуючи різницю в наданні допомоги пацієнтам з інсультом у лПЗ різного рівня, для покращення надання допомоги пацієнтам в Одеській області впроваджують концепцію «Телемедицина при інсульті», яка $€$ комплексною системою, спрямованою на методологічну та координаційну допомогу від фрахівців-експертів. Стандартну операційну процедуру надання догоспітальної допомоги при ГПМК наведено в таблиці 2.

Таблиця 2. Алгоритм надання екстреної медичної допомоги хворим на догоспітальному етапі

\begin{tabular}{|c|c|c|c|}
\hline $\begin{array}{c}\text { № } \\
3 a / n \\
\end{array}$ & Необхідні дії & $\begin{array}{c}\text { Час } \\
\text { виконання } \\
\end{array}$ & Виконавці \\
\hline 1 & $\begin{array}{l}\text { І. Алгоритм прийому виклику диспетчером від хворого, родичів або } \\
\text { сімейного лікаря. } \\
\text { Питання, які повинен задати диспетчер людині, яка телесонує } \\
\text { (форма № 109/о) (додаток № 1): } \\
\text { І етап. Причина виклику (необхідно запідозрити гостре порушення мозкового } \\
\text { кровообігу у разі наступних відповідей): } \\
\text { а) асиметричне обличчя; } \\
\text { б) порушення рухів, асиметричні рухи; } \\
\text { в) порушення мовлення, або проблеми з розумінням мовлення; } \\
\text { г) головний біль, який з'явився раптово; } \\
\text { ґ) головний біль з блювотою, з'явився раптово; } \\
\text { д) раптова втрата свідомості; } \\
\text { е) затерпання кінцівок з одного боку, половини обличчя або однієї половини } \\
\text { тулуба. Асиметричне відчуття затерпання; } \\
\text { є) проблеми з ходою, втрата балансу; } \\
\text { ж) проблеми з зором (одно- або двосторонні), які з'явилися зненацька. } \\
\text { ІІ етап. Місце виклику (позначити): } \\
\text { а) квартира; } \\
\text { б) робоче місце; } \\
\text { в) вулиця; } \\
\text { г) громадське місце; } \\
\text { ґ) лікувальний заклад; } \\
\text { д) водойма; } \\
\text { е) навчальний заклад; } \\
\text { є) школа. } \\
\text { ІІІ етап. Адреса хворого: } \\
\text { а) область; } \\
\text { б) населений пункт; } \\
\text { в) вулиця (без номеру будинку та квартири). } \\
\text { При підозрі на гостре порушення мозкового кровообігу позначити пріоритет } \\
\text { виклику як «Екстрений з високим пріоритетом» та передати первинну карту } \\
\text { виклику екстреної медичної допомоги диспетчеру передачі виклику виїзним } \\
\text { бригадам Е(ш)Мд }\end{array}$ & $\begin{array}{l}45 \text { с для } \\
\text { направ- } \\
\text { лення } \\
\text { бригади } \\
\text { ЕМД }\end{array}$ & $\begin{array}{l}\text { диспетчер } \\
\text { приймання } \\
\text { викликів } \\
\text { «103» }\end{array}$ \\
\hline
\end{tabular}




\begin{tabular}{|c|c|c|c|}
\hline \begin{tabular}{|c|} 
№ \\
3a/n/ח
\end{tabular} & Необхідні дії & $\begin{array}{c}\text { Час } \\
\text { виконання }\end{array}$ & Виконавці \\
\hline 2 & $\begin{array}{l}\text { II. Термінове направлення бригади екстреної медичної допомоги за } \\
\text { адресою (на місце події) }\end{array}$ & до 2 хв & \begin{tabular}{|l} 
диспетчер \\
передачі \\
виклику \\
виїзним \\
бригадам \\
Е(Ш)МД \\
\end{tabular} \\
\hline 3 & $\begin{array}{l}\text { Після цього продовжити заповняти необхідні поля: } \\
\text { Точна адреса: } \\
\text { а) будинок; } \\
\text { б) корпус; } \\
\text { в) під’їзд; } \\
\text { г) поверх; } \\
\text { ґ) номер квартири; } \\
\text { д) код до під'їзду (якщо є). } \\
\text { 4 етап. Ефективність дихання: } \\
\text { а) нормальне дихання; } \\
\text { б) дихання відсутнє; } \\
\text { в) ускладнене дихання; } \\
\text { г) немає можливості визначити; } \\
\text { ґ) поверхневе дихання; } \\
\text { д) агональне дихання. } \\
\text { 5 етап. Наявність свідомості: } \\
\text { а) притомний; } \\
\text { б) непритомний; } \\
\text { в) притомний, не реагує; } \\
\text { г) притомний, не адекватно відповідає на питання; } \\
\text { ґ) немає можливості встановити; } \\
\text { д) не визначено. } \\
\text { 6 етап: } \\
\text { а) прізвище хворого; } \\
\text { б) вік хворого; } \\
\text { в) стать хворого; } \\
\text { г) хто викликає, уточнити контактний телефон. } \\
\text { Уточнюючі питання, які можна додати в вільне поле причини виклику: } \\
\text { ґ) чи може хворий підняти одночасно } 2 \text { руки («так», «ні»); } \\
\text { д) чи є хворого порушення мовлення («так», «ні»); } \\
\text { е) час виникнення вищеперерахованих симптомів, чи коли востаннє бачили } \\
\text { пацієнта без вказаних симптомів. } \\
\text { Внести додаткову інорормацію до картки 109/о, переключити абонента на } \\
\text { лікаря-консультанта } \\
\end{array}$ & до 1 хв & $\begin{array}{l}\text { диспетчер } \\
\text { приймання } \\
\text { викликів } \\
\text { «103» }\end{array}$ \\
\hline 4 & $\begin{array}{l}\text { III. Поради абоненту: } \\
\text { 1. Забезпечте хворому постільний режим. } \\
\text { 2. Покладіть хворого лежачи з піднятою злегка головою. } \\
\text { 3. Поміряйте артеріальний тиск, якщо це можливо. } \\
\text { 4. Створіть хворому спокійну обстановку. } \\
\text { 5. Не давайте хворому їсти та пити. } \\
\text { 6. Знайдіть лікарські засоби, які приймає хворий, та приготуйте їх до приїзду } \\
\text { бригади екстреної медичної допомоги. } \\
\text { 7. Не залишайте хворого без нагляду. } \\
\text { 8. Перевіряйте дихання кожні } 2 \text { хв. } \\
\text { 9. У випадку зупинки дихання розпочніть серцево-легеневу реанімацію зі } \\
\text { співвідношенням } 30 \text { компресій грудної клітки на глибину 5-6 см, почергово з } \\
\text { 2 штучними подихами. } \\
\text { 10. Поясніть родичам хворого, хто є кандидатом на тромболізис та } \\
\text { тромбоекстракцію, переваги тромболітичної терапії та умови надання медичної } \\
\text { допомоги }\end{array}$ & & $\begin{array}{l}\text { лікар- } \\
\text { консультант }\end{array}$ \\
\hline 5 & IV. Прибуття бригади екстреної медичної допомоги на місце події & $\begin{array}{l}\text { до } 10 \text { хв } \\
\text { у містах } \\
\text { та } 20 \text { хв } \\
\text { у сільській } \\
\text { місцевості }\end{array}$ & $\begin{array}{l}\text { бригада } \\
\text { Е(Ш)МД }\end{array}$ \\
\hline
\end{tabular}




\begin{tabular}{|c|c|c|c|}
\hline \begin{tabular}{|c|} 
№ \\
3a/ח
\end{tabular} & Необхідні дії & $\begin{array}{c}\text { Час } \\
\text { виконання }\end{array}$ & Виконавці \\
\hline 6 & 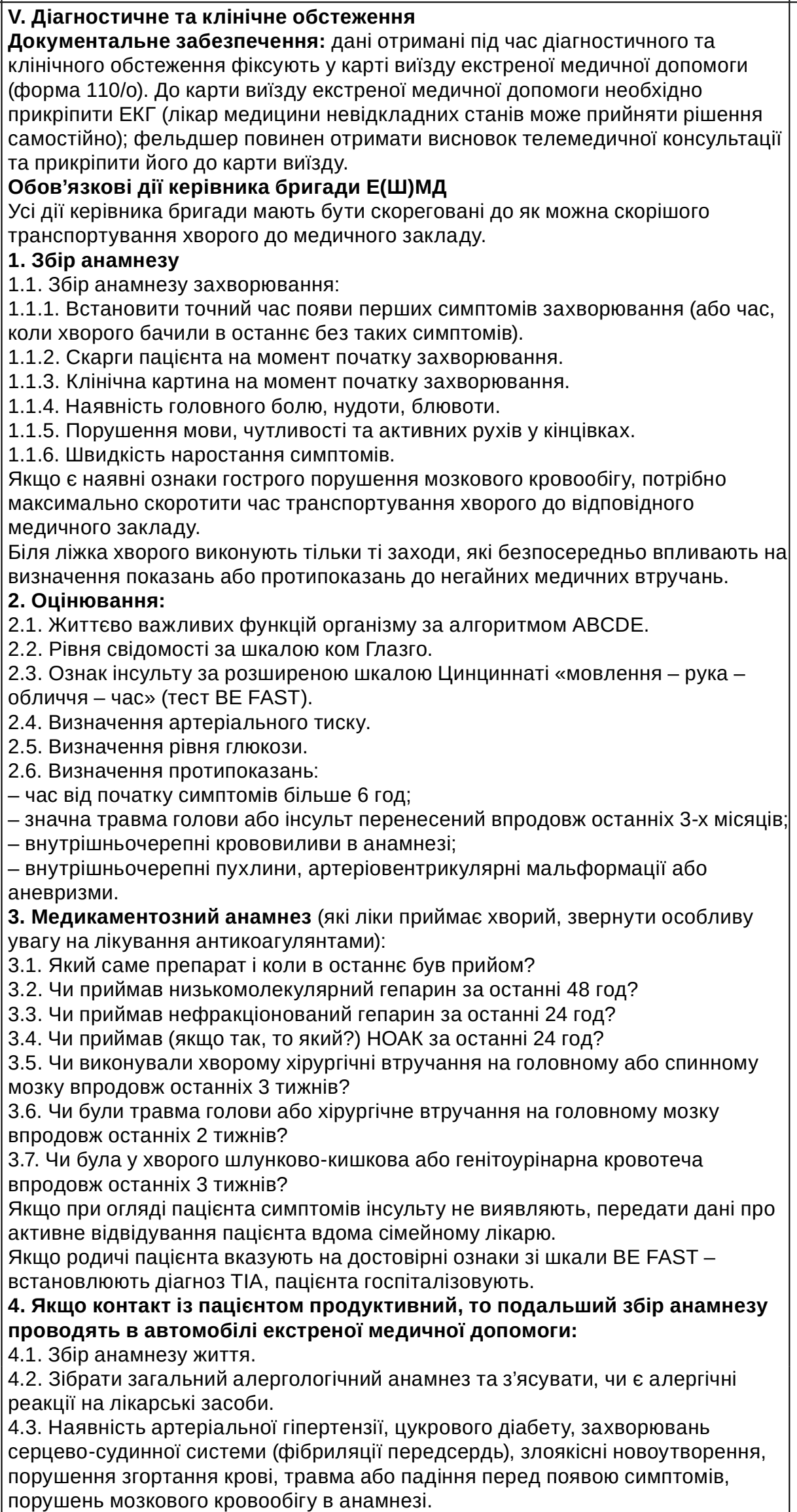 & & $\begin{array}{l}\text { лікар або } \\
\text { фрельдшер } \\
\text { бригади } \\
\text { Е(Ш)МД }\end{array}$ \\
\hline
\end{tabular}




\begin{tabular}{|c|c|c|c|}
\hline \begin{tabular}{|c|} 
№ \\
$3 a / n$
\end{tabular} & Необхідні дії & \begin{tabular}{|c|} 
Час \\
виконання
\end{tabular} & Виконавці \\
\hline & $\begin{array}{l}\text { 4.4. Уточнити хірургічні втручання, які проводили впродовж попередніх } \\
\text { 3-х місяців; } \\
\text { 4.5. Амбулаторне та стаціонарне лікування, яке проходив хворий; } \\
\text { 4.6. Час останнього прийому їжі. } \\
\text { 5. Огляд пацієнта в автомобілі екстреної медичної допомоги: } \\
\text { Оцінювання життєво важливих функцій організму за алгоритмом АВCDE - } \\
\text { переоцінка статусу кожні } 5 \text { хв. } \\
\text { 5.1. Оцінювання ключових елементів соматичного статусу (аускультація серця } \\
\text { та легень, пальпація живота). } \\
\text { 5.2. Оцінити неврологічний статус хворого: } \\
\text { 5.2.1. Рівень свідомості (за шкалою ком Глазго) - переоцінка статусу кожні } \\
\text { 5 хв. } \\
\text { 5.2.2. Ознаки інсульту за шкалою «мовлення - рука - обличчя - час» } \\
\text { (тест ҒАSт) - переоцінка статусу кожні } 5 \text { хв. } \\
\text { 5.2.3. Визначити інші порушення соматичного статусу. } \\
\text { 5.2.4. Інструментальні обстеження. } \\
\text { 5.2.5. Визначення артеріального тиску кожні } 5 \text { хв. } \\
\text { 5.2.6. Вимірювання температури тіла. } \\
\text { 5.2.7. ЕКГ (лікар може приймати рішення самостійно, фельдшер зобов'язаний } \\
\text { передати біометричні ЕКГ-сигнали у консультативний телеметричний центр для } \\
\text { вирішення термінових питань інтерпретації ЕКГ). } \\
\text { 5.2.8. Пульсоксиметрія (визначення сатурації крові киснем, норма - 95 \%) }\end{array}$ & & \\
\hline 7 & 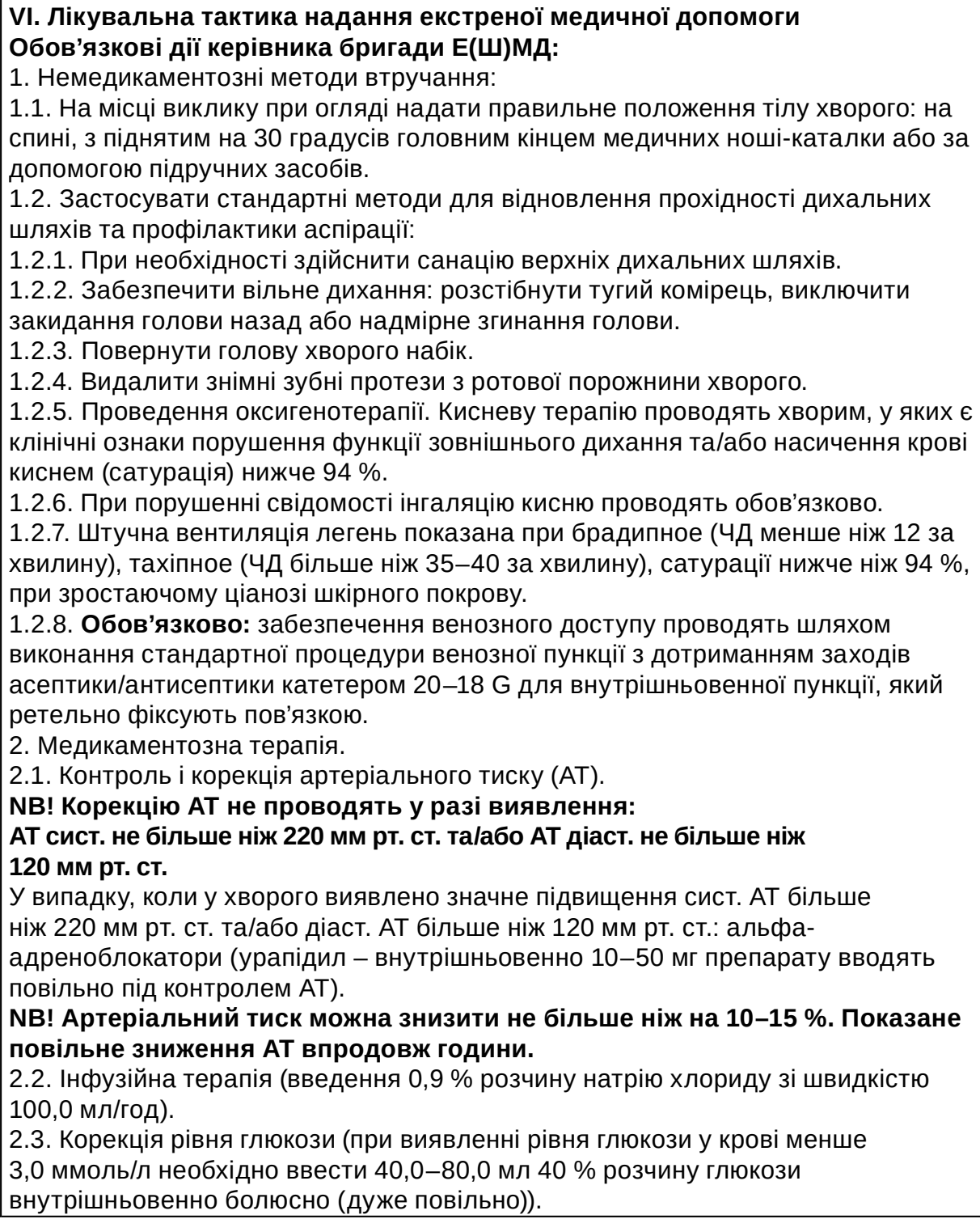 & & $\begin{array}{l}\text { лікар або } \\
\text { фрельдшер } \\
\text { бригади } \\
\text { Е(ш)МД }\end{array}$ \\
\hline
\end{tabular}




\begin{tabular}{|c|c|c|c|}
\hline \begin{tabular}{|c|} 
№ \\
$3 a / n$
\end{tabular} & Необхідні дії & $\begin{array}{c}\text { Час } \\
\text { виконання }\end{array}$ & Виконавці \\
\hline & $\begin{array}{l}\text { 2.4. Протисудомна терапія (діазепам - внутрішньовенно 10-20 мг (2,0- } \\
\text { 4,0 мл 0,5 \% розчину), у разі необхідності повторного введення - } 20 \text { мг } \\
\text { внутрішньовенно). } \\
\text { NB! Заборонені втручання у хворого з підозрою на гпмк: } \\
\text { 1. Застосування діуретиків для лікування набряку мозку. } \\
\text { 2. Введення розчинів глюкози } 5 \text { \%, колоїдних розчинів для інфузійної терапії. } \\
\text { 3. Призначення ацетилсаліцилової кислоти або іншої антитромбоцитарної } \\
\text { терапії до проведення нейровізуалізації. } \\
\text { 4. Сублінгвальне та внутрішньом'язове введення антигіпертензивних } \\
\text { лікарських засобів у зв'язку непередбаченим фрармакодинамічним ефектом. } \\
\text { 5. Застосування ніфедипіну короткої дії, оскільки швидкість та ступінь зниження } \\
\text { Ат при його прийомі (особливо сублінгвально) складно контролювати, у зв'язку } \\
\text { 3 чим підвищується ризик ішемії мозкових або вінцевих судин. } \\
\text { 6. Введення папаверину гідрохлориду. } \\
\text { 7. Введення нефракціонованого гепарину, гепарину низької молекулярної маси } \\
\text { і гепариноїдів. } \\
\text { 8. Застосування кальцію хлориду, етамзилату, менадіону обо аскорбінової } \\
\text { кислоти для зупинки кровотечі при підозрі на геморагічний інсульт. } \\
\text { 9. Нейропротекторних та ноотропних лікарських засобів, а також бурштинової } \\
\text { кислоти. } \\
\text { 10. Внутрішньом'язове введення будь-яких препаратів }\end{array}$ & & \\
\hline 8 & 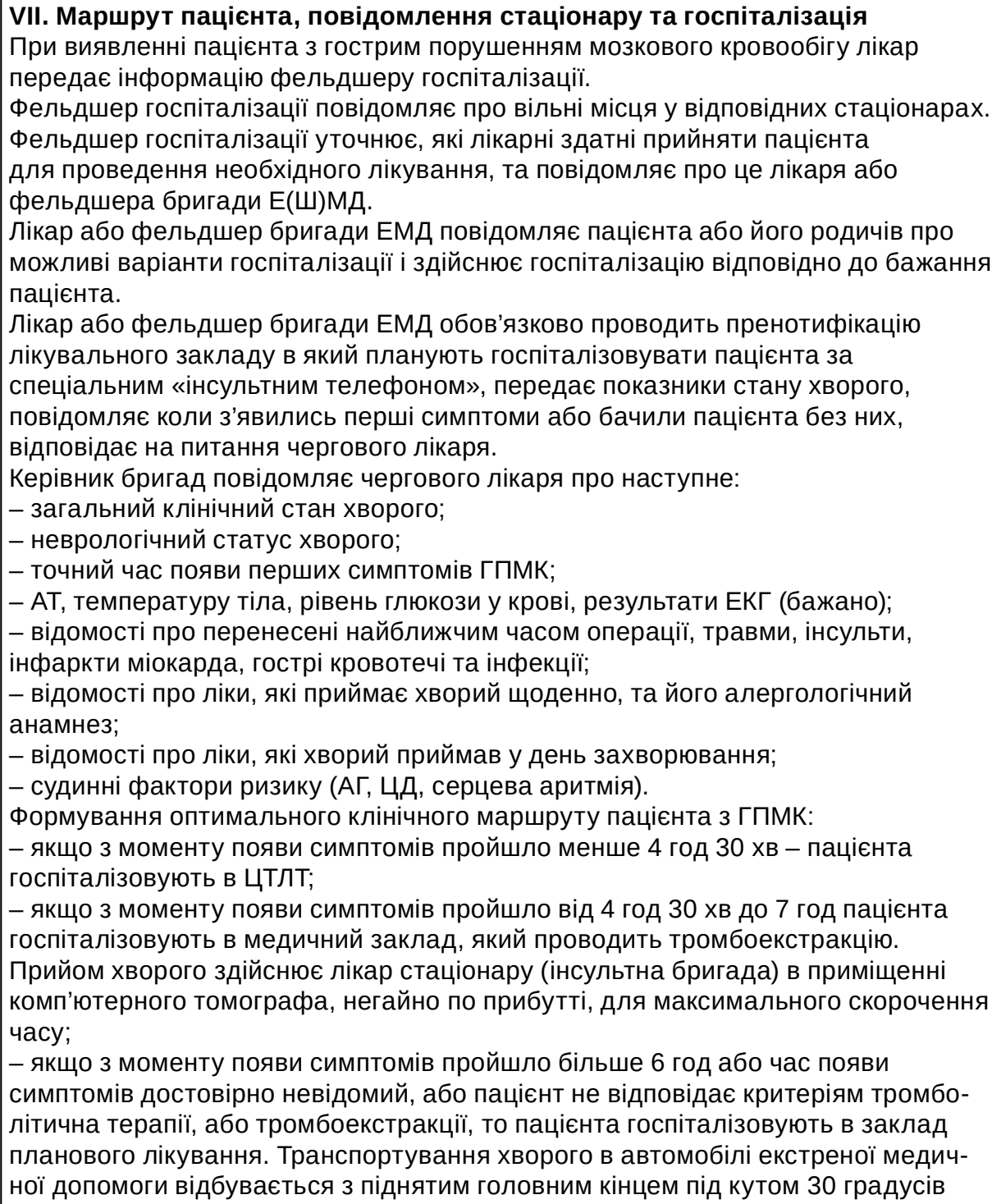 & $\begin{array}{l}\text { госпіта- } \\
\text { лізація } 3 \\
\text { ближньої } \\
\text { зони } \\
60 \text { хв, } 3 \\
\text { дальньої - } \\
90 \text { хв }\end{array}$ & $\begin{array}{l}\text { лікар або } \\
\text { фельдшер } \\
\text { бригади } \\
\text { Е(ш)МД }\end{array}$ \\
\hline
\end{tabular}




\begin{tabular}{|c|c|c|c|}
\hline \begin{tabular}{c|} 
№ \\
3a/ח
\end{tabular} & Необхідні дії & \begin{tabular}{c|} 
Час \\
виконання
\end{tabular} & Виконавці \\
\hline 9 & $\begin{array}{l}\text { VIII. Індикатори якості медичної допомоги ЕМд: } \\
\text { 1. Наявність в бригаді екстреної медичної допомоги регіонального клінічного } \\
\text { маршруту пацієнта з підозрою на ішемічний інсульт у «період вікна } \\
\text { терапевтичних можливостей» на догоспітальному етапі медичної допомоги в } \\
\text { даному 3ОЗ. } \\
\text { 2. Матеріально-технічне забезпечення відповідно до табеля. } \\
\text { 3. Виконання нормативу прийому виклику диспетчером ЄОдс та направлення } \\
\text { бригади екстреної медичної допомоги (не більше } 1 \text { хв). } \\
\text { 4. Час від первинного медичного контакту до початку госпіталізації пацієнта в } \\
\text { спеціалізований стаціонар бригадою ЕМд } 60 \text { хв (м. Одеса), } 90 \text { хв - по території } \\
\text { Одеської області за межами } 30 \text { км зони від м. Одеси. } \\
\text { 5. Зміни стану пацієнта розцінювати як новий статус пацієнта. } \\
\text { 6. У разі відмови від госпіталізації - } 100 \text { \% заповнення фрорми відмови } \\
\text { (передати у відділ контролю якості - передзвонити і спитати чому відмовились). } \\
\text { 7. Дії відповідно до регіонального клінічного маршруту пацієнта } \\
\text { бригадою Е(Ш)Мд. } \\
\text { 8. Госпіталізація хворого з ознаками гпмк до } 6 \text { год у лікарню інтенсивної } \\
\text { допомоги для проведення системного тромболізису або тромбоекстракції. } \\
\text { 9. Госпіталізація в лікарню планового лікування, якщо симптоми з'явились } \\
\text { більше ніж } 6 \text { год, достовірно не відомо початок появи симптомів або наявність } \\
\text { протипоказань }\end{array}$ & $\begin{array}{l}100 \% \\
100 \% \\
100 \% \\
100 \% \\
100 \% \\
100 \% \\
100 \% \\
100 \%\end{array}$ & \\
\hline
\end{tabular}

\section{Висновки}

1. Впровадження ресорми покращило якість догоспітальної допомоги при інсульті, так кількість відмов від госпіталізації за наявності інсульту зменшилася у 2,5 раза, кількість пацієнтів, яких доставили до лікарні в рамках терапевтичного вікна на ЗПСШ, зросла на 36,3 \%.

2. Залишається актуальною проблема необґрунтованих відмов пацієнтів із ГПМК та їхніх родичів від термінової госпіталізації.

3. Поряд із розвитком мережі спеціалізованих лікувально-профрілактичних закладів для надання допомоги при ГПМК доцільне впровадження стандартизованих операційних процедур надання догоспітальної допомоги, спрямованих на зменшення часу транспортування пацієнтів до лікарні.

Перспективи подальших досліджень пов'язані з оцінкою ефективності функціонування системи догоспітальної допомоги при інсульті в умовах реформування вторинної ланки медичної системи в Україні.

\section{Список літератури}

1. Анализ времени доезда скорой медицинской помощи при инсульте в Екатеринбурге / О. С. Стародубцева, В. А. Широков, С. В. Бегичева, Г. А. Осинкин // Уральский медицинский журнал. - 2017. - № 10 (154). - С. 53-57.

2. Зозуля І. С. Догоспітальний етап ішемічного інсульту : «час - це мозок» / І. С. Зозуля, О. П. Мошенська, А. О. Камінський // Український медичний часопис. - 2010. - № 5. - С. 89-93.

3. Монгуш Х. Д. Медицинская помощь больным с инсультом на этапах скорой помощи / Х. Д. Монгуш, А. Б. Ондар, Р. Ч. Чылбак-оол // Сибирский медицинский журнал. - 2013. - № 3. - С. 81-84.

4. Про затвердження та впровадження медико-технологічних документів зі стандартизації екстреної медичної допомоги : наказ МОЗ України від 05.06.2019 р. № 1269 [Електронний ресурс]. - Режим доступу : https://moz.gov. ua/article/ministry-mandates/nakaz-moz-ukraini-vid-05062019--1269-pro-zatverdzhennja-ta-vprovadzhennja-medikotehnologichnih-dokumentiv-zi-standartizacii-ekstrenoi-medichnoi-dopomogi.

5. Новини МОЗ України. У 2020 році лікування гострого мозкового інсульту є пріоритетом в програмі медичних гарантій [Електронний ресурс]. - Режим доступу : https://moz.gov.ua/article/news/u-2020-roci-likuvannja-gostrogomozkovogo-insultu-e-prioritetom-v-programi-medichnih-garantij.

6. Пути повышения качества скорой медицинской помощи при госпитализации больных с острыми нарушениями мозгового кровообращения / М. А. Милосердов, Н. Н. Маслова, Ю. С. Корнева, О. О. Фролкова // Медицинский альманах. - 2015. - № 4 (39). - С. 135-138.

7. Реперфузійні центри в Україні [Електронний ресурс]. - Режим доступу : https://moz.gov.ua/kardiocentri.

Список літератури

8. Davis S. M. Prehospital stroke care: The next big thing / S. M. Davis, G. A. Donnan // Int. J. Stroke. - 2019. - Vol. 14 (6). P. 563.

9. Emergency department door-to-puncture time since 2014 / A. L. Czap, J. C. Grotta, S. A. Parker [et al.] // Stroke. 2019. - Vol. 50 (7). - P. 1774-1780. 
10. Factors associated with shortening of prehospital delay among patients with acute ischemic stroke / R. Soto-Cámara,

J. González-Santos, J. González-Bernal [et al.] // J. Clin. Med. - 2019. - Vol. 8 (10). - E1712.

11. Geographic analysis of mobile stroke unit treatment in a dense urban area: The New York City METRONOME Registry /

B. R. Kummer, M. P. Lerario, M. D. Hunter // J. Am. Heart Assoc. - 2019. - Vol. 8 (24). - P. e013529.

12. Global stroke statistics / A. G. Thrift, T. Thayabaranathan, G. Howard [et al.] // Int. J. Stroke. - 2017. - Vol. 12 (1). P. 13-32.

13. Gomez C. R. Time is brain: The stroke theory of relativity / C. R. Gomez // J. Stroke Cerebrovasc Dis. - 2018. Vol. 27 (8). - P. 2214-2227.

14. Guidelines for the early management of patients with acute ischemic stroke: 2019 update to the 2018 guidelines for the early management of acute ischemic stroke: A guideline for healthcare professionals from the American Heart Association / American Stroke Association / W. J. Powers, A. A. Rabinstein, T. Ackerson [et al.] // Stroke. - 2019. - Vol. 50 (12). P. e344-e418.

15. Impact on prehospital delay of a stroke preparedness campaign: A SW-RCT (Stepped-Wedge Cluster Randomized Controlled Trial) / L. Denti, C. Caminiti, U. Scoditti [et al.] // Stroke. - 2017. - Vol. 48 (12). - P. 3316-3322.

16. Is door-to-needle time reduced for emergency medical services transported stroke patients routed directly to the computed tomography scanner on emergency department arrival? / B. Sloane, N. Bosson, N. Sanossian [et al.] // J. Stroke Cerebrovasc. Dis. - 2020. - Vol. 29 (1). - P. 104477.

17. Kettner M. Mobile Stoke Unit : Changes in the concept of stroke care over time / M. Kettner, S. Walter, K. Fassbender // Radiologe. - 2019. - Vol. 59 (7). - P. 622-626.

18. Long-term implementation of a prehospital severity scale for EMS triage of acute stroke: a real-world experience / M. A. Jumaa, A. C. Castonguay, H. Salahuddin [et al.] // J. Neurointerv. Surg. - 2020. - Vol. 12 (1). - P. $19-24$.

19. Novel use of prehospital telemedicine to decrease door to computed tomography results in acute strokes / M. Bilotta, A. P. Sigal, A. Shah [et al.] // J. Healthc Qual. - 2019. doi: 10.1097/JHQ.0000000000000229.

20. Paramedic initiated lisinopril for acute stroke treatment (PIL-FAST): Results from the pilot randomised controlled trial / L. Shaw, C. Price, S. McLure [et al.] // Emerg. Med. J. - 2014. - Vol. 31 (12). - P. 994-999.

21. Planning of stroke care and urgent prehospital care across Europe: Results of the ESO/ESMINT/EAN/SAFE Survey / S. Abilleira, D. A. de Sousa, T. Gattringer [et al.] // Eur. Stroke J. - 2019. - Vol. 4 (4). - P. 329-336.

22. Prehospital and emergency department-focused mission protocol improves thrombolysis metrics for suspected acute stroke patients / D. Y. Madhok, K. J. Keenan, S. B. Cole [et al.] // J. Stroke Cerebrovasc. Dis. - 2019. - Vol. 28 (12). P. 104423.

23. Prehospital stroke care. New prospects for treatment and clinical research / H. J. Audebert, J. L. Saver, S. Starkman [et al.] // Neurology. - 2013. - Vol. 81. - P. 501-508.

24. Prehospital stroke management optimized by use of clinical scoring vs mobile stroke unit for triage of patients with stroke: A randomized clinical trial / S. A. Helwig, A. Ragoschke-Schumm, L. Schwindling [et al.] // JAMA Neurol. - 2019. P. E1-E9. doi: 10.1001/jamaneurol.2019.2829.

25. PRESTO investigators. Prehospital triage of patients with suspected stroke symptoms (PRESTO): protocol of a prospective observational study / E. Venema, M. H. C. Duvekot, H. F. Lingsma [et al.] // BMJ Open. - 2019. - Vol. 9 (7). P. e028810.

26. Reasons for prehospital delay in acute ischemic stroke / J. Fladt, N. Meier, S. Thilemann [et al.] // J. Am. Heart Assoc. 2019. - Vol. 8 (20). - P. e013101.

27. RIGHT-2 Investigators. Prehospital transdermal glyceryl trinitrate in patients with ultra-acute presumed stroke (RIGHT-2): an ambulance-based, randomised, sham-controlled, blinded, phase 3 trial. Lancet. - 2019. - Vol. 393 (10175). - P. 10091020.

28. Stead T. G. Large Vessel Occlusion Identification Through Prehospital Administration of Stroke Scales: A County-wide Emergency Medical Services Prospective Research Protocol / T. G. Stead, P. R. Banerjee, L. Ganti // Cureus. - 2019. Vol. 11 (10). - P. e5931.

29. Technological innovation for prehospital stroke triage: ripe for disruption / J. C. Martinez-Gutierrez, R. V. Chandra, J. A. Hirsch, T. Leslie-Mazwi // J. Neurointerv. Surg. - 2019. - Vol. 11 (11). - P. 1085-1090.

\section{References}

1. Starodubtseva, O.S., Shirokov, V.A., Begicheva, S.V., \& Osinkin, G.A. (2017). Analiz vremeni doyezda skoroy meditsinskoy pomoshchi pri insulte $v$ Yekaterinburge [Analysis of the time of the ambulance in stroke in Yekaterinburg]. Uralskiy meditsinskiy zhurnal - Ural Medical Journal, 10 (154), 53-57 [in Russian].

2. Zozulya, I.S., Moshenskaya, O.P., \& Kaminskiy, A.A. (2010). Dohospitalnyi etap ishemichnoho insultu : "chas - tse mozok" [Pre-hospital stage of ischemic stroke: "time is the brain"]. Ukrayinskyi medychnyi chasopys - Ukrainian Medical Journal, 5, 89-93 [in Ukrainian].

3. Mongush, H.M., Ondar, A.B., \& Chylbakool, R.Ch. (2013). Meditsinskaya pomoshch bolnym s insultom na etapakh skoroy pomoshchi [Medical care for patients with stroke at the stages of ambulance]. Sib. Med. zhurn. (Irkutsk). - Sib. Med. Journal (Irkutsk), 3, 81-84 [in Russian].

4. Nakaz MOZ Ukrainy № 1269 vid 5.06.2019 “Pro zatverdzhennia ta vprovadzhennia medyko-tekhnolohichnykh dokumentiv zi standartyzatsii ekstrennoi medychnoi dopomohy" - Order of the Ministry of Health of Ukraine No. 1269 of June 5, 2019 "On Approval and Implementation of Medical and Technological Documents on Standardization of Emergency Medical Assistance". Retrieved from: https://moz.gov.ua/article/ministry-mandates/nakaz-moz-ukraini-vid-05062019--1269-prozatverdzhennja-ta-vprovadzhennja-mediko-tehnologichnih-dokumentiv-zi-standartizacii-ekstrenoi-medichnoi-dopomogi [in Ukrainian]. 
5. Novyny MOZ Ukrainy. U 2020 rotsi likuvannia hostroho mozkovoho insultu ie priorytetom $v$ prohrami medychnykh harantii [Ministry of Health of Ukraine. In 2020, the treatment of acute stroke is a priority in the medical guarantee program]. Retrieved from: https://moz.gov.ua/article/news/u-2020-roci-likuvannja-gostrogo-mozkovogo-insultu-e-prioritetom-vprogrami-medichnih-garantij [in Ukrainian].

6. Miloserdov, M.A., Maslova, N.N., Korneva, Yu.S., \& Frolkova, O.O. (2015). Puti povysheniya kachestva skoroy meditsinskoy pomoshchi pri gospitalizatsii bolnykh s ostrymi narusheniyami mozgovogo krovoobrashcheniya [Ways to improve the quality of emergency care during hospitalization of patients with acute cerebrovascular accident]. Meditsinskiy almanakh - Medical Almanac, 4 (39), 135-138 [in Russian].

7. Reperfuziini tsentry v Ukraini [Reperfusion centers in Ukraine]. Retrieved from: https://moz.gov.ua/kardiocentri.

8. Davis, S.M., \& Donnan, G.A. (2019). Prehospital stroke care: The next big thing. Int. J. Stroke, 14 (6), 563.

9. Czap, A.L., Grotta, J.C., Parker, S.A., Yamal, J.M., Bowry, R., Sheth, S.A., ..., \& Jagolino-Cole, A.L. (2014). Emergency Department Door-to-Puncture Time Since 2014. Stroke, 50 (7), 1774-1780.

10. Soto-Cámara, R., González-Santos, J., González-Bernal, J., Martín-Santidrian, A., Cubo, E., \& Trejo-Gabriel-Galán, J.M. (2019). Factors associated with shortening of prehospital delay among patients with acute ischemic stroke. J. Clin. Med., 8 (10), E1712.

11. Kummer, B.R., Lerario, M.P., Hunter, M.D., Wu, X., Efraim, E.S., Salehi Omran, S., Chen, M.L., ..., \& Fink, M.E. (2019). Geographic Analysis of Mobile Stroke Unit Treatment in a Dense Urban Area: The New York City METRONOME Registry. J Am. Heart Assoc., 8 (24), e013529.

12. Thrift, A.G., Thayabaranathan, T., Howard, G., Howard, V.J., Rothwell, P.M., Feigin, V.L., ..., \& Cadilhac, D.A. (2017). Global stroke statistics. Int. J. Stroke, 12 (1), 13-32.

13. Gomez, C.R. (2018). Time is brain: The stroke theory of relativity. J. Stroke Cerebrovasc. Dis., 27 (8), $2214-2227$.

14. Powers, W.J., Rabinstein, A.A., Ackerson, T., Adeoye, O.M., Bambakidis, N.C., Becker, K., ..., \& Tirschwell, D.L. (2019). Guidelines for the early management of patients with acute ischemic stroke: 2019 update to the 2018 guidelines for the early management of acute ischemic stroke: A guideline for healthcare professionals from the American Heart Association/ American Stroke Association. Stroke, 50 (12), e344-e418.

15. Denti, L., Caminiti, C., Scoditti, U., Zini, A., Malferrari, G., Zedde, M.L., ..., \& Schulz, P.J. (2017). Impact on prehospital delay of a stroke preparedness campaign: A SW-RCT (Stepped-Wedge Cluster Randomized Controlled Trial). Stroke, 48 (12), 3316-3322.

16. Sloane, B., Bosson, N., Sanossian, N., Saver, J.L., Perez, L., \& Gausche-Hill, M. (2020). Is door-to-needle time reduced for emergency medical services transported stroke patients routed directly to the computed tomography scanner on emergency department arrival? J. Stroke Cerebrovasc. Dis., 29 (1), 104477.

17. Kettner, M., Walter, S., \& Fassbender, K. (2019). Mobile stoke unit : Changes in the concept of stroke care over time. Radiologe, 59 (7), 622-626.

18. Jumaa, M.A., Castonguay, A.C., Salahuddin, H., Shawver, J., Saju, L., Burgess, R., ..., Zaidi, S.F. (2020). Long-term implementation of a prehospital severity scale for EMS triage of acute stroke: a real-world experience. J. Neurointerv. Surg., 12 (1), 19-24.

19. Bilotta, M., Sigal, A.P., Shah, A., Martin, A., Schlappy, D.A., Sorensen, G., \& Barbera, C. (2019). A novel use of prehospital telemedicine to decrease door to computed tomography results in cute strokes. J. Healthc Qual. DOI: 10.1097/ JHQ.0000000000000229.

20. Shaw, L., Price, C., McLure, S., Howel, D., McColl, E., Younger, P., \& Ford, G.A. (2014). Paramedic initiated lisinopril for acute stroke treatment (PIL-FAST): Results from the pilot randomised controlled trial. Emerg. Med. J., 31 (12), $994-999$. 21. Abilleira, S., de Sousa, D.A., Gattringer, T., Kobayashi, A., Fazekas, F., Szikora, I., ..., \& Fischer, U. (2019). Planning of stroke care and urgent prehospital care across Europe: Results of the ESO/ESMINT/EAN/SAFE Survey. Eur. Stroke J., 4 (4), 329-336.

22. Madhok, D.Y., Keenan, K.J., Cole, S.B., Martin, C., \& Hemphill, J.C. 3rd. (2019). Prehospital and emergency departmentfocused mission protocol improves thrombolysis metrics for suspected acute stroke patients. J. Stroke Cerebrovasc. Dis., 28 (12), 104423.

23. Audebert, H.J., Saver, J.L., Starkman, S., Lees, K.R., \& Endres, M. (2013). Prehospital stroke care. New prospects for treatment and clinical research. Neurology, 81, 501-508.

24. Helwig, S.A., Ragoschke-Schumm, A., Schwindling, L., Kettner, M., Roumia, S., Kulikovski, J., ..., \& Fassbender, K. (2019). Prehospital stroke management optimized by use of clinical scoring vs mobile stroke unit for triage of patients with stroke: A randomized clinical trial. JAMA Neurol., E1-E9.

25. Venema, E., Duvekot, M.H.C., Lingsma, H.F., Rozeman, A.D., Moudrous, W., Vermeij, F.H., ..., \& Roozenbeek, B. (2019). PRESTO investigators. Prehospital triage of patients with suspected stroke symptoms (PRESTO): protocol of a prospective observational study. BMJ Open, 9 (7), e028810.

26. Fladt, J., Meier, N., Thilemann, S., Polymeris, A., Traenka, C., Seiffge, D.J., ..., \& De Marchis, G.M. Reasons for prehospital delay in acute ischemic stroke. J. Am. Heart Assoc., 8 (20), e013101.

27. (2019). RIGHT-2 Investigators. Prehospital transdermal glyceryl trinitrate in patients with ultra-acute presumed stroke (RIGHT-2): an ambulance-based, randomised, sham-controlled, blinded, phase 3 trial. Lancet, 393 (10175), 1009-1020.

28. Stead, T.G., Banerjee, P.R., \& Ganti, L. (2019). Large vessel occlusion identification through prehospital administration of stroke scales: A county-wide emergency medical services prospective research protocol. Cureus, 11 (10), e5931.

29. Martinez-Gutierrez, J.C., Chandra, R.V., Hirsch, J.A., \& Leslie-Mazwi, T. (2019). Technological innovation for prehospital stroke triage: ripe for disruption. J Neurointerv Surg., 11 (11), 1085-1090. 


\section{PREHOSPITAL MEDICAL CARE FOR ACUTE CEREBROVASCULAR ACCIDENT. THE FIRST RESULTS OF THE REFORM ON THE EXAMPLE OF ODESA REGION}

T. M. Muratova ${ }^{1}$, D. M. Khramtsov ${ }^{1}$, O. M. Stoyanov ${ }^{1}$, Yu. M. Vorokhta ${ }^{1}$, D. O. Samofalov', S. S. Larchenko ${ }^{3}$, S. O. Malonoga ${ }^{3}$ ${ }^{1}$ Odesa National Medical University, Odesa, Ukraine

${ }^{2}$ South Interregional Department of the National Health Service of Ukraine, Odesa, Ukraine

${ }^{3}$ Odesa Regional Center for Emergency Medical Services and Disaster Medicine, Odesa, Ukraine

Purpose: to evaluate the effectiveness of the provision of prehospital care for stroke in the context of reforming the national health system using the example of the Odesa region.

Materials and Methods. A retrospective analysis of the activities of emergency medical care was carried out in 2016-2018 (before the implementation of the reform) and in 2018-2019.

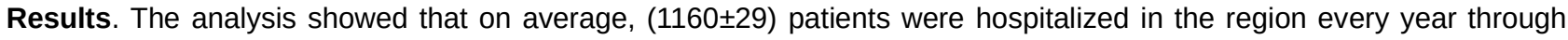
the EMC system, which is 47.7 cases per 100.000 population. The mean age of patients hospitalized for EMC was (62.6 \pm 3.8$)$ years, with a gender ratio of $1 / 1.2$ with a slight male predominance. The largest number of stroke cases was recorded in summer (61.4\%). About $25-30 \%$ of emergency medical care calls are not completed by the hospitalization of a stroke patient. The reasons for refusal are related to the wish of the patient or his relatives to be treated on an outpatient basis $(13.5 \%)$, the presence of physicians or medical professionals among the relatives (11.7 \%), lack of funds (18.9\%), family circumstances $(6.3 \%)$, the general serious condition of the patient (4.5\%). After the introduction of the new concept of emergency care, the number of hospital refusals in the presence of stroke decreased by 2.5 times, the number of patients admitted to the hospital within the therapeutic window increased by $36.3 \%$. The experience of creating regional clinical and transport protocols for maximum time reduction and optimal treatment at all stages of care is discussed.

Conclusion. The implementation of the reform improved the quality of pre-hospital care for stroke, the number of refusals from hospitalization in the presence of stroke decreased by 2.5 times, the number of patients admitted to the hospital within the therapeutic window increased by $36.3 \%$. The problem of unreasonable refusals of patients with stroke and their relatives from urgent hospitalization remains crucial. The introduction of standardized operating procedures for the provision of prehospital care aimed at reducing the time for patients transportation to the hospital is discussed.

KEY WORDS: acute cerebrovascular accident; prehospital phase; medical care; public health.

Рукопис надійшов до редакції 20.01.2020 p.

\section{Відомості про авторів:}

Муратова Тетяна Миколаївна - доктор медичних наук, доцент, директор Центру реконструктивної та відновної медицини (Університетська клініка) Одеського національного медичного університету.

Храмцов Деніс Миколайович - кандидат медичних наук, керівник інсультної служби неврологічного відділення Центру реконструктивної та відновної медицини (Університетська клініка) Одеського національного медичного університету.

Стоянов Олександр Миколайович - професор, професор кафедри неврології та нейрохірургії Одеського національного медичного університету.

Ворохта Юрій Миколайович - кандидат медичних наук, лікар-невропатолог неврологічного відділення Центру реконструктивної та відновної медицини (Університетська клініка) Одеського національного медичного університету.

Самофалов Дмитро Олександрович - кандидат медичних наук, заступник директора Південного міжрегіонального департаменту Національної служби охорони здоров'я України.

Ларченко Світлана Семенівна - заступник головного лікаря Відокремленого підрозділу «Одеська станція екстреної (швидкої) медичної допомоги» КНП «Одеський обласний центр екстреної медичної допомоги і медицини катастроф».

Малонога Світлана Олександрівна - начальник Єдиної оперативно-диспетчерської служби КНП «Одеський обласний центр екстреної медичної допомоги і медицини катастрофр». 